\title{
PERANCANGAN PROGRAM EKOWISATA KERAJINAN TANGAN KOTA PALEMBANG PROVINSI SUMATERA ELATAN
}

\author{
(The Program Design of Handicraft Ecotourism Palembang City, South Sumatra \\ Province)
}

\author{
Kania Sofiantina Rahayu'), Anida Shafa Salsabila Putri ${ }^{1)}$ \\ 1) Program Studi Ekowisata, Sekolah Vokasi, IPB University \\ E-mail : kaniasofia@apps.ipb.ac.id
}

\begin{abstract}
Palembang City has a diversity of cultural resources. Art is the cultural element that reflects the characteristics of an area. The Handicraft is one of Palembang City's arts which has the potential as a tourist attraction. Handicraft ecotourism has influences in preserving handicraft products, improving the economy, and the welfare of traditional craftsmen in Palembang City. This research aims to inventory and identify the handicraft resources in Palembang city to support the eco-tourism program design in South Sumatra Province. The method used is literature study, interview, direct observation, and the questionnaire distribution. The inventoried handicraft tourism resources are divided into two classifications, namely handicrafts with hard materials and soft materials. There are four handicrafts in Palembang City, consisting of one hard material handcraft and three soft material handicrafts. The handicraft resources were analyzed based on the seven assessment indicators from Avenzora (2008) to get the superior handicraft resources' potential assessment results. The superior handicrafts potentials in Palembang are Laker, Songket, Jumputan, and wood carving. Based on the identification results, it shows that the Stakeholders agree and are ready if Palembang handicrafts are included in the ecotourism program object. The Ecotourism program is designed with the handicraft exploration concept that involves interaction between the tourists and the craftsmen. The handicraft ecotourism program is expected to stimulate regional economic growth through the resource arranged by the community.
\end{abstract}

\section{Key Word: Ecotourism, Palembang City's Handicrafts}




\section{PENDAHULUAN}

Keanekaragaman sumber daya alam dan budaya menjadi kekayaan bagi negara Indonesia. Keragaman budaya, suku, jenis makanan, kerajinan tangan merupakan kearifan lokal yang menjadikan negara Indonesia sebagai negara yang memiliki kekhasan. Kekayaan sumber daya alam dan budaya Indonesia merupakan potensi yang sangat besar bagi bidang pariwisata apabila keunikannya dikelola dengan baik. Pengelolaan potensi pariwisata yang baik akan berpengaruh terhadap aspek perekonomian negara Indonesia.

Menurut Hasan (2015) menyatakan bahwa ekowisata sebagai pariwisata berkelanjutan dapat meminimalisir dampak negatif terhadap lingkungan dan budaya lokal serta membantu menghasilkan pekerjaan bagi masyarakat setempat di masa depan. Ekowisata merupakan bentuk pariwisata yang dikembangkan di daerah-daerah alami yang tujuannya adalah untuk mengakui dan menghargai alam dan budaya lokal yang meliputi tindakan konservasi dan memastikan keterlibatan aktif, menghasilkan manfaat bagi penduduk setempat.

Kota Palembang merupakan kota besar di Provinsi Sumatera Selatan yang memiliki keanekaragaman sumber daya alam dan budaya. Budaya lokal Palembang yang melibatkan keaktifan masyarakat dapat memberikan manfaat bagi masyarakat itu sendiri jika dikelola dengan baik. Pengelolaan budaya lokal dapat dilakukan melalui kegiatan wisata yang berbasiskan ekowisata agar kegiatan pariwisata dapat berkelanjutan.

Kesenian merupakan salah satu unsur budaya yang mengekspresikan masyarakat daerah sehingga menjadi ciri khas daerah tersebut. Seni kerajinan pada dasarnya merupakan cerminan nilai budaya suatu masyarakat, dimana di dalamnya terkandung nilai sejarah, sosial dan estetik (Mubarat, 2016). Kerajinan tangan Kota Palembang merupakan bagian dalam kesenian yang memiliki keunggulan dari keunikan bentuk dan dibuat berdasarkan kreativitas serta keterampilan pengrajinnya. Penggunaan alat dan bahan tradisional dalam proses pembuatan kerajinan tangan menjadi daya tarik bagi pengunjung atau wisatawan sehingga kerajinan tangan berpotensi untuk dijadikan obyek dalam kegiatan ekowisata. Kesederhanaan alat-alat mampu menciptakan hasil karya yang indah dan menjadi nilai lebih pada kerajinan (Sefmiwati, 2016).

Ekowisata kerajinan tangan merupakan suatu upaya dalam melestarikan produk kerajinan, meningkatkan perekonomian dan menyejahterakan para pengrajin tradisional di Kota Palembang. Produk kerajinan tangan Kota Palembang perlu dikelola dengan baik agar budaya dan eksistensi kerajinan tangan kota Palembang tetap terjaga. Salah satu upaya yang dilakukan dalam mengelola kerajinan tangan Kota Palembang yaitu memasukan atraksi kerajinan tangan ke dalam rancangan program ekowisata. Dukungan Stakeholders sangat berperan penting dalam terwujudnya program ekowisata tersebut. Tujuan penelitian ini adalah menginventarisasi dan mengidentifikasi sumber daya kerajinan tangan agar dapat dijadikan objek dalam rancangan program ekowisata di Kota Palembang Provinsi Sumatera Selatan 


\section{METODE PENELITIAN}

Jenis data pada penelitian ini terdiri dari data primer dan sekunder. Data primer sebagai data pokok atau utama yang dibutuhkan selama penulisan berupa sumber daya kerajinan tangan Kota Palembang dan data kesiapan Stakeholders. Data sekunder sebagai data pendukung kelengkapan data utama selama melakukan penulisan berupa kondisi umum Kota Palembang. Teknik pengambilan data dilakukan dengan metode studi literatur, observasi langsung dan kuesioner.

Pengambilan data secara observasi langsung dilakukan dengan mendatangi pusat-pusat produksi kerajinan tangan yang berada di Kota Palembang. Pengambilan data melalui wawancara dilakukan dengan mewawancarai langsung pengelola terkait lokasi penyebaran objek-objek kerajinan tangan. Teknik wawancara yang dilakukan menggunakan teknik Snowball Sampling, yaitu pengambilan sampel dengan bantuan key-informant, dan dari key-informant tersebut akan berkembang sesuai petunjuknya (Subagyo, 2006). Pengambilan sample dimulai dari sampel yang awalnya kecil, kemudian sampel tersebut mengarahkan penulis kepada teman-temannya yang lain untuk dijadikan sampel (Sugiyono, 2013). Pengambilan data sumber daya kerajinan tangan diawali dengan mewawancarai petugas Dinas Pariwisata Kota Palembang terkait kerajinan tangan dan para pengrajin kerajinan tangan di setiap Kecamatan Kota Palembang.

Penyusunan program ekowisata diawali dengan menentukan sumber daya unggulan yang dinilai menggunakan indikator penilaian potensi sumber daya ekowisata. Data dalam penilaian potensi unggulan sumber daya wisata dilakukan melalui pengisian kuesioner oleh asesor. Pihak yang berperan sebagai asesor dalam penelitian ini yaitu pihak Dinas Pariwisata Kota Palembang. Penilaian sumber daya unggulan merujuk kepada indikator penilaian Avenzora (2008) mengenai penilaian potensi sumber daya wisata.

Tabel 1 Indikator Penilaian Potensi Sumber daya Ekowisata

\begin{tabular}{|c|c|c|}
\hline No. & Aspek & Penjelasan \\
\hline 1. & Keunikan & $\begin{array}{l}\text { Menggambarkan nilai eksistensi suatu } \\
\text { obyek atau event dalam konteks } \\
\text { kepariwisataan }\end{array}$ \\
\hline 2. & Kelangkaan & $\begin{array}{l}\text { Representatif komparatif dari intangible } \\
\text { suatu objek wisata terhadap objek sejenis } \\
\text { lainnya }\end{array}$ \\
\hline 3. & Keindahan & $\begin{array}{l}\text { Nilai ekstrinsik dan intrinsik yang dimiliki } \\
\text { sutau obyek dalam memberikan sebuah } \\
\text { kepuasan wisatawan dalam melihat } \\
\text { benda tersebut }\end{array}$ \\
\hline 4. & Seasonalitas & $\begin{array}{l}\text { Menggambarkan waktu ketersediaan } \\
\text { suatu obyek untuk dapat diakses } \\
\text { wistaawan dalam memenuhi kepuasan } \\
\text { dari kegiatan wisata yang dilakukan }\end{array}$ \\
\hline
\end{tabular}




\begin{tabular}{|c|c|c|}
\hline No. & Aspek & Penjelasan \\
\hline 5. & Aksesibilitas & $\begin{array}{l}\text { Menggambarkan kondisi dan progress } \\
\text { yang harus dilakukan wisatawan untuk } \\
\text { mendatangi obyek wisata yang akan } \\
\text { dikunjungi }\end{array}$ \\
\hline 6. & Sensifitas & $\begin{array}{l}\text { Menggambarkan tata nilai pariwisata } \\
\text { berkelanjutan dalam menilai pengaruh } \\
\text { kegiatan wisata terhadap berkelanjutan } \\
\text { obyek itu sendiri atau elemen lingkungan } \\
\text { sekitarnya }\end{array}$ \\
\hline 7. & Fungsi Sosial & $\begin{array}{l}\text { Memberikan pemaparan tentang adanya } \\
\text { potensi berbagai dampak sosial yang } \\
\text { terjadi dalam kegiatan kawasan }\end{array}$ \\
\hline
\end{tabular}

Penilaian potensi sumber daya ekowisata menggunakan nilai skala Likert 15 untuk mengukur tentang fenomena sosial (Sugiyono, 2010). Instrumen penilaian dibuat dalam bentuk centang ataupun pilihan ganda. Jawaban dari setiap instrument mempunyai gradasi dari sangat positif sampai sangat negatif yang dapat berubah kata-kata antara lain: (5) sangat setuju, (4) setuju, (3) raguragu/netral, (2) tidak setuju, (1) sangat tidak setuju (Soegeng, 2006). Jawaban positif diberi nilai terbesar dan jawaban negatif diberi nilai terkecil (Sugiyono, 2012).

Data Stakeholders diperoleh dengan metode observasi langsung, wawancara dan penyebaran kuesioner. Pengambilan data secara observasi langsung dengan mendatangi lokasi pengelola objek kerajinan tangan dan melakukan wawancara juga penyebaran kuesioner. Teknik yang digunakan yaitu purposive sampling.

Penyusunan program ekowisata dilakukan dengan metode observasi langsung dan menganalisis sumber daya kerajinan tangan yang ada di Kota Palembang. Penyusunan program ekowisata terdiri dari sumber daya unggulan yang dinilai menggunakan indikator penilaian potensi sumber daya ekowisata (Avenzora, 2008). Tahapan dalam penyusunan program ekowisata kerajinan adalah mengidentifikasi sumber daya ekowisata kerajinan tangan yang berpotensi untuk kegiatan wisata, mengidentifikasi Stakeholder yang terlibat dalam program ekowisata, menentukan lokasi, tempat, waktu dan sasaran pelaksanaan program, menentukan tujuan, manfaat, durasi kegiatan dan sasaran dalam pelaksanaan program, menentukan konsep program, membuat gambaran dari kegiatan yang dapat dilakukan dalam program tersebut.

\section{HASIL DAN PEMBAHASAN}

Kota Palembang memiliki keanekaragaman sumber daya kerajinan tangan. Hasil identifikasi menunjukkan bahwa kerajinan tangan di Kota Palembang dibagi menjadi dua klasifikasi, yaitu kerajinan tangan bahan keras dan kerajinan tangan 
bahan lunak. Kerajinan tangan diklasifikasikan berdasarkan penggunaan bahannya. Bahan padat digunakan untuk kerajinan tangan yang bersifat keras dan bahan lunak lunak digunakan untuk kerajianan tangan yang bersifat lunak. Hasil inventarisasi sumber daya kerajinan tangan di Kota Palembang berdasarkan klasifikasi kerajinan bahan keras dan lunak terdapat pada Tabel 2.

Tabel 2 Inventarisasi Kerajinan Tangan di Kota Palembang

\begin{tabular}{|c|c|c|c|c|c|}
\hline \multirow[b]{2}{*}{ No. } & \multirow[b]{2}{*}{$\begin{array}{c}\text { Nama Kerajinan } \\
\text { Tangan }\end{array}$} & \multicolumn{2}{|c|}{ Klasifikasi } & \multirow[b]{2}{*}{ Penyebaran } & \multirow[b]{2}{*}{$\begin{array}{c}\text { Keterang } \\
\text { an }\end{array}$} \\
\hline & & $\begin{array}{l}\text { Bahan } \\
\text { Keras }\end{array}$ & $\begin{array}{l}\text { Bahan } \\
\text { Lunak }\end{array}$ & & \\
\hline 1. & $\begin{array}{l}\text { Ukiran Kayu } \\
\text { Palembang }\end{array}$ & $\checkmark$ & & $\begin{array}{l}\text { Kec. Bukit } \\
\text { Kecil }\end{array}$ & Alami \\
\hline 2. & Kerajinan Laker & & $\checkmark$ & $\begin{array}{l}\text { Kec. Bukit } \\
\text { Kecil } \\
\text { Kec. Ilir Barat }\end{array}$ & Buatan \\
\hline 3. & Kain Songket & & $\checkmark$ & $\begin{array}{l}\text { Il dan } \\
\text { Jakabaring }\end{array}$ & Buatan \\
\hline 4. & Kain Jumputan & & $\checkmark$ & $\begin{array}{l}\text { Kec. } \\
\text { Jakabaring }\end{array}$ & Buatan \\
\hline
\end{tabular}

\section{Kerajinan Tangan Bahan Keras}

Berdasarkan hasil inventarisasi sumber daya kerajinan tangan pada Tabel 2 menunjukkan bahwa Kota Palembang memiliki kerajinan tangan berbahan keras, yaitu kerajinan ukiran kayu Palembang yang mengunakan bahan utama kayu alami. Jenis kayu yang dapat digunakan dalam ukiran Palembang diantaranya kayu Medang, Merawan, Sungkai, Ulin dan Tembesu. Jenis kayu yang banyak digunakan pengrajin yaitu kayu Tembesu. Kayu Tembesu memiliki sifat yang sulit kering karena jenis kayunya berminyak. Sifat kayu yang berminyak membuat kayu Tembesu memiliki ketahanan terhadap rayap.

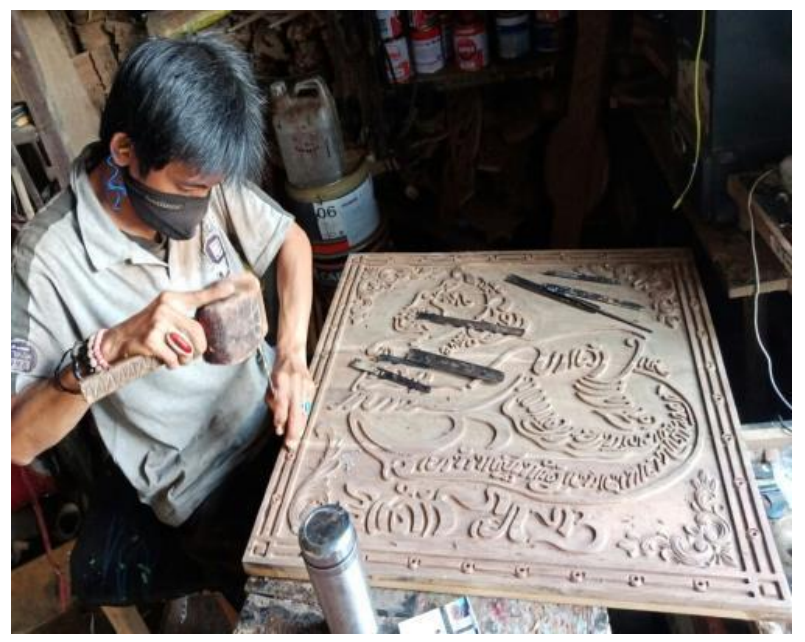

Gambar 1 Ukiran Kayu Palembang pada Kerajinan Tangan Bahan Keras

Seni ukiran Palembang memiliki gaya yang khas yaitu warna emas sebagai pelapis ukiran. Ukiran kayu banyak dipengaruhi oleh budaya asing seperti India, 
China dan budaya dari daerah lain seperti Jepara, Pekalongan dan Solo dan dikembangkan secara turun-temurun. Ukiran kayu biasanya diterapkan pada peralatan rumah tangga sebagai estetika keindahan. Seiring dengan perkembangan zaman fungsi ukiran Palembang terus mengalami perkembangan. Ukiran kayu dapat ditemukan dalam beberapa bentuk seperti tongkat, mimbar masjid, kotak hias kecil, mimbar, meja, lemari pengantin, kursi, puade (tempat pengantin bersanding) dan papan nama.

Motif ukiran Kayu Palembang pada dasarnya terdiri dari dua yaitu jenis Patro dan Pakis. Jenis Patro merupakan motif yang berbentuk sedikit merambat sedangkan jenis pakis memiliki tingkat kesulitan lebih tinggi. Jenis pakis banyak dikembangkan dengan adanya unsur buah seperti sirsak, salak dan anggur. Motif yang sering digunakan berbentuk bunga atau bunga jalar. Ragam hias yang terdapat pada seni ukiran kayu Palembang berdasarkan sejarah masa Kesultanan mengartikan sebagai perlambang kebudayaan.

Proses pembuatan kerajinan tangan ini masih menggunakan peralatan dan bahan-bahan yang terbilang tradisional, seperti Cetakan Pola yang terbuat dari Karton, Mesin Bor, Gergaji Piring (Circular Saw), Jig Saw, Gerinda Tangan dan Duduk, Mesin Amplas Getar, Alat Pahat dan Pewarnaan. Proses pembuatan ukiran kayu Palembang terdiri dari beberapa tahapan pembuatan. Berikut kerangka proses pembuatan kerajinan tangan ukiran kayu.

\section{Kerajinan Tangan Bahan Lunak}

Produk kerajinan bahan lunak biasanya terbuat dari material bersifat lunak, baik dari bahan alami seperti serat alam, tanah liat dan kulit hewan maupun buatan seperti bubur koran atau kertas, sabun dan lilin. Kerajinan Laker, kain Songket dan Jumputan merupakan contoh kerajinan tangan berbahan lunak.

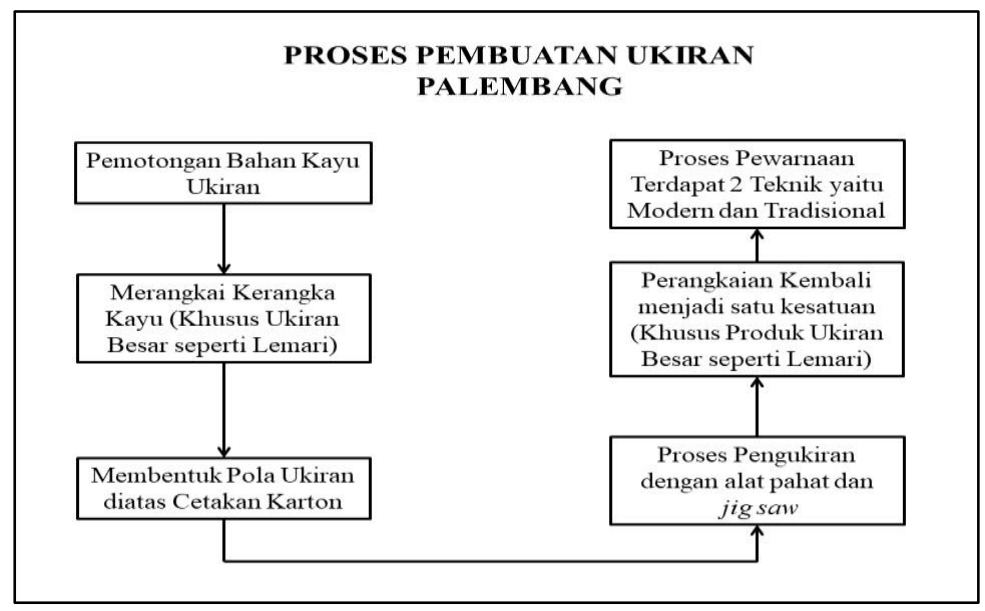

Gambar 2 Kerangka Pembuatan Ukiran Palembang

\section{Kerajinan Laker}

Kerajinan Laker mulanya berasal dari Negeri Jepang dan dikembangkan oleh Bangsa China. China kemudian memperkenalkan kerajinan Laker kepada masyarakat Palembang. Pengaruh budaya China cukup kuat jika dilihat dari ragam hias serta motif yang diterapkan pada kerajinan Laker tersebut. Laker merupakan 
bahan akhir untuk melapisi dan mengawetkan kerajinan kayu. Laker ini berfungsi untuk memberikan nilai-nilai estetika yang diterapkan pada alat-alat rumah tangga seperti lemari pakaian, baki, guci hias dan lainnya. Seiring perkembangan zaman kerajinan Laker ini pun kian mengalami modifikasi. Kerajinan Laker tidak hanya diterapkan pada kerajinan berbahan kayu melainkan pada kerajinan berbahan keramik dan media seni lukis.

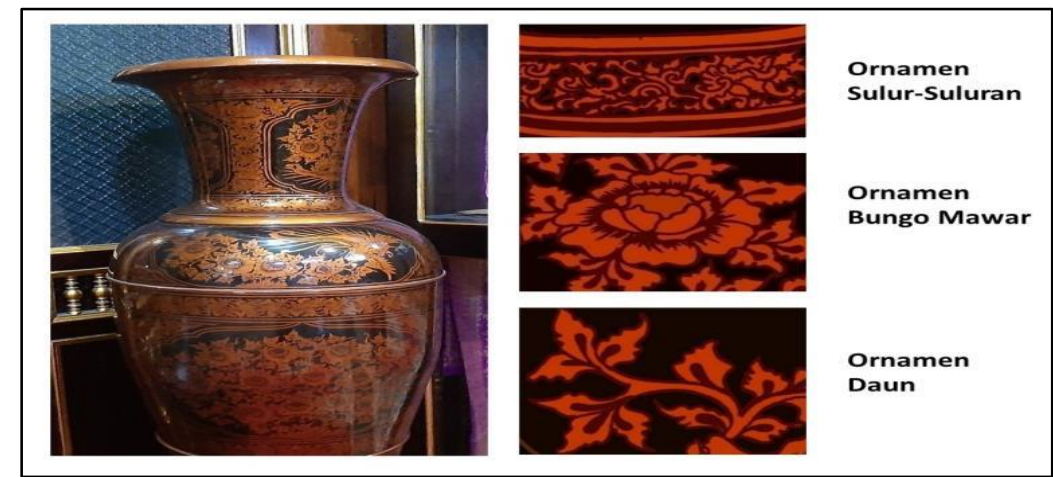

Gambar 3 Aplikasi Kerajinan Laker pada Guci

\section{Kain Songket Palembang}

Kain Songket sudah dikenal sejak zaman kedatuan Sriwijaya, dimana pada zaman tersebut digunakan sebagai usaha sampingan para penduduk asli Palembang. Kain Songket merupakan kerajinan tradisional yang diwajibkan bagi para gadis remaja ketika hendak berumah tangga. Kerajinan Songket berdampak pada kemakmuran rakyat Sumatera Selatan. Hubungan perdagangan dan kebudayaan dengan Tiongkok dan Siam membuat kerajianan Songket menjadi berkembang. Kebudayaan luar telah mempengaruhi motif dan keragaman kain Songket. Kain Songket biasa dipakai dalam kegiatan adat seperti upacara adat yang pada umumnya digunakan oleh para wanita terutama dalam upacara pernikahan dan upacara penyambutan tamu yang digunakan oleh penari dahulu kala.

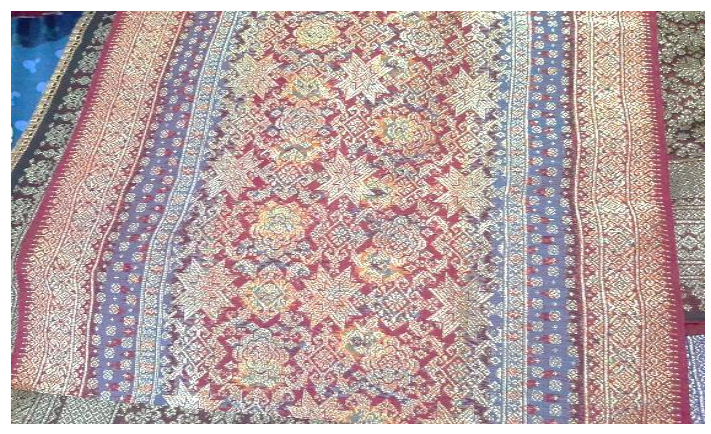

Gambar 4 Kain Songket Palembang

Kain Songket dibuat dengan Alat Tenun Bukan Mesin (ATBM) atau gedongan. Alat tradisional tersebut terdiri dari beberapa bagian di dalamnya yang mendukung pembuatan kain Songket, seperti Dayan dan Cacak, Apit, Por atau Lempaut, Beliro, Suri, Gulungan dan Nyicing, Pelipiran dan Gun, Peting atau Plenting, Benang Emas dan Penguluran. Komposisi motif Kain Songket biasanya 
dikelompokan menjadi tiga bagian, yaitu, motif geometris, tumbuhan dan campuran. Masing-masing motif mempunyai makna sekaligus simbol dalam kehidupan manusia. Seperti motif tumbuhan yang melekat pada kain Songket memiliki makna bahwa dalam manusia tidak dapat terlepas dari unsur alam dalam menjalankan kehidupannya sedangkan motif geometris dan campuran hanya sebagai hiasan estetika keindahan pada kain. Ragam kain Songket diantaranya Lepus, Tawur, Tretes, Bungo Pacik, Limar dan motif kombinasi. Keunikan motif kain Songket Lepus terletak pada benang emas menutupi bagian kain sehingga terlihat mewah.

Penggunaan kain Songket pada kegiatan-kegiatan upacara adat seperti pernikahan. Hal ini merupakan upaya atau bentuk pelestarian kain Songket. Seiring dengan perkembangan zaman, kini kain Songket tidak hanya diaplikasikan pada pakaian saja melainkan pada tas, souvenir pernikahan, dompet dan barangbarang cenderamata lainnya.

\section{Kain Jumputan}

Kain Jumputan biasa disebut dengan kain pelangi atau kain celup ikat. Kain Jumputan merupakan bentuk jenis kain Parola India dan Cinde Jawa yang dibuat sesuai dengan kebutuhan masyarakat lokal Palembang. Keanekaragaman motif kain Cinde atau Patola India sesuai dengan ideologi budaya lokal Palembang Keindahan corak dan warna kain Jumputan menunjukkan nilai seni yang tinggi. Keterampilan pengrajin sangat mempengaruhi kualitas keanggunan corak dan warna kain Jumputan. Satu pasang kain Jumputan biasanya memiliki tema warna yang sama dan terdiri dari bahan untuk bagian atas, bawah, dan selendang.

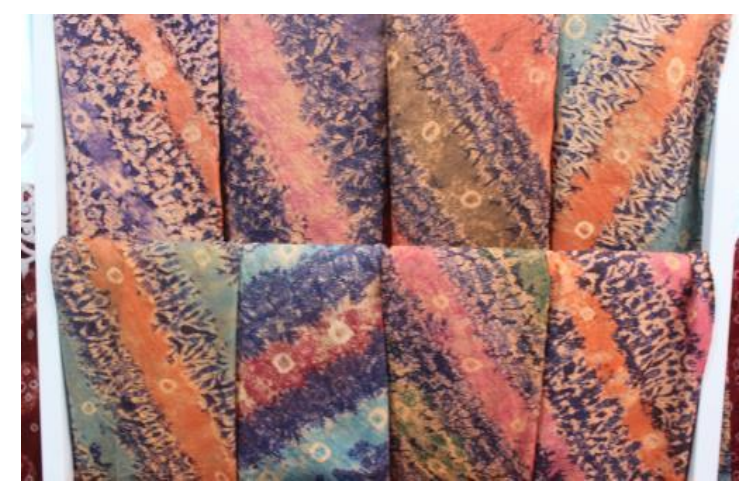

Gambar 5 Kain Jumputan Palembang

Perbedaan kain Jumputan Palembang dan Jawa terletak pada warna dan proses penjumputan yang dilakukan. Kain Jumputan Palembang cenderung berwarna terang dan proses pewarnaannya secara berulang. Kain Jumputan di daerah Jawa cenderung menggunakan warna dengan tone natural. Kain Jumputan Palembang juga memiliki khas pada motif yang padat sedangkan Jumputan di daerah Jawa memiliki motif yang lebih berjarak atau renggang antar motif lainnya. Masyarakat biasa menggunakan kain Jumputan sebagai acara adat pernikahan, tarian dan acara keluarga. Seiring perkembangan zaman, kain Jumputan tidak hanya sebagai acara adat tetapi juga sebagai kebutuhan rumah 
tangga, taplak meja, sarung, pakaian santai. Ragam teknik pembuatan Jumputan menambah nilai fungsi kain tersebut.

\section{Penilaian Potensi Kerajinan Tangan Unggulan}

Penilaian kerajinan tangan unggulan di Kota Palembang dilakukan untuk mengetahui kerajinan tangan yang berpotensi untuk dijadikan sebagai obyek dalam kegiatan program ekowisata. Penilaian dilakukan oleh asesor yang memahami bidang kerajinan tangan dan industri ekonomi kreatif. Penilaian potensi sumber daya kerajinan tangan unggulan di kota Palembang terdapat pada Tabel 3.

Tabel 3 Penilaian Potensi Sumber daya Kerajinan Tangan Unggulan

\begin{tabular}{|c|c|c|c|c|c|c|c|c|c|}
\hline \multirow{2}{*}{ No. } & \multirow{2}{*}{ Nama Obyek } & \multicolumn{7}{|c|}{ Indikator } & \multirow{2}{*}{$\begin{array}{l}\text { Rata- } \\
\text { Rata }\end{array}$} \\
\hline & & A & B & C & D & $E$ & $\mathrm{~F}$ & G & \\
\hline 1. & $\begin{array}{l}\text { Kerajinan Laker } \\
\text { Palembang }\end{array}$ & 5 & 5 & 5 & 3 & 2 & 5 & 5 & 4,30 \\
\hline 2. & $\begin{array}{l}\text { Kain Songket } \\
\text { Palembang }\end{array}$ & 5 & 4 & 5 & 3 & 2 & 5 & 5 & 4,14 \\
\hline 3. & $\begin{array}{l}\text { Kain Jumputan } \\
\text { Palembang }\end{array}$ & 4 & 4 & 5 & 3 & 2 & 5 & 5 & 4,00 \\
\hline 4. & $\begin{array}{l}\text { Kerajinan Ukir Kayu } \\
\text { Palembang }\end{array}$ & 4 & 4 & 4 & 3 & 2 & 5 & 5 & 3,90 \\
\hline
\end{tabular}

Keterangan. A Keunikan, B. Kelangkaan, C. Keindahan, D. Musiman, E. Sensivitas, F. Aksesibilitas, G. Fungsi Sosial

Keterangan nilai indikator: Keunikan: 1. Sangat tidak unik, 2. Tidak unik, 3. Biasa saja, 4. Unik, 5. Sangat unik. Kelangkaan: 1. Sangat tidak langka, 2. Tidak langka, 3. Biasa saja, 4. Langka, 5. Sangat langka. Keindahan: 1. Sangat tidak indah, 2. Tidak indah, 3. Biasa saja, 4. Indah, 5. Sangat indah. Musiman: 1. Sangat tidak musiman, 2. Tidak musiman, 3. Biasa saja, 4. Musiman, 5. Sangat musiman. . Sensitivitas: 1. Sangat tidak sensitif, 2. Tidak sensitif, 3. Biasa saja, 4. Sensitif, 5. Sangat sensitif. Aksesibilitas: 1. Sangat tidak terjangkau, 2. Tidak terjangkau, 3. Biasa saja, 4. Terjangkau, 5. Sangat terjangkau Fungsi Sosial: 1. Sangat tidak bermanfaat, 2. Tidak bermanfaat, 3. Biasa saja, 4.bermanfaat, 5 .Sangat bermanfaat.

Hasil penilaian kerajinan tangan tertinggi oleh asesor yaitu kerajinan Laker Palembang. Kerajinan Laker dinilai sangat unik karena Laker memiliki ciri khas dari segi warna dan hasil akhir yang mengkilau. Kerajinan Laker dinilai sangat langka karena kerajinan ini jarang dimiliki daerah lain. Keindahan kerajinan Laker terlihat dari segi bentuk, komposisi warna yang serasi menjadi kesatuan kerajinan yang sangat menarik. Aspek seasonalitas pada kerajinan Laker dinilai biasa saja karena saat ini eksistensi kerajinan Laker dapat ditemukan pada waktu kapan pun, tidak terbatas pada waktu atau musim tertentu. Penilaian kerajinan Laker dari aspek sensivitas dinilai tidak sensitif. Eksistensi kerajinan Laker tidak berubah dengan adanya interaksi pengunjung yang belum memahami aturan khusus dalam pemanfaatan Laker. Proses pembuatan Laker tidak menimbulkan dampak negatif terhadap lingkungan. Material alami seperti Ambalau tetap digunakan dan tidak merusak lingkungan karena penggunaan masih dalam batas sewajarnya. Penilaian kerajinan Laker dari aspek aksesibilitas dinilai sangat terjangkau karena kerajinan Laker dapat ditemukan di dua lokasi yaitu di Kampung 19 Ilir pusat kerajinan ukir dan Sanggar Seni Ganesha di Kecamatan Bukit Kecil yang lokasinya 
mudah dijangkau pengunjung. Kerajinan Laker dari aspek fungsi sosial dinilai sangat bermanfaat. Kerajinan Laker pada masa lalu dipercaya oleh masyarakat Palembang memiliki sejarah yang kuat sehingga kerajinan Laker dijadikan sebagai benda seserahan dalam adat tradisional Palembang. Penggunaan kerajinan Laker sampai saat ini masih digunakan dalam acara adat walaupun saat ini kerajinan Laker juga banyak digunakan sebagai benda perlengkapan untuk sehari-hari.

Produk unggulan kedua yaitu kain Songket Palembang. Kain Songket Palembang dalam memiliki keunikan karena memiliki ragam motif khas yang berbeda dengan Songket daerah lain. Kain Songket termasuk dalam salah satu aset kerajinan tangan Palembang dan produk kerajinan tangan yang banyak diketahui oleh masyarakat luas karena keunikan pada motifnya. Kerajinan Songket Palembang dinilai langka karena kerajinan Songket Palembang hanya ada di Kota Palembang dan Kabupaten Ogan Ilir Provinsi Sumatera Selatan.

Hasil penilaian asesor terhadap produk unggulan ketiga kerajinan tangan Kota Palembang yaitu kain Jumputan Palembang. Kain Jumputan memiliki desain yang unik dan terkenal dengan ciri khas penggunaan warna cerah dan menggunakan banyak motif pada seluruh bahan kain sehingga kain ini pun terlihat sangat indah. Penilaian kain Jumputan pada aspek seasonalitas dinilai biasa saja karena kain dapat dilihat dan dinikmati pada waktu kapan saja tanpa batasan usia, musim atau periode tertentu. Penggunaan pewarna yang cukup banyak pada pembuatan kain Jumputan tidak berpengaruh terhadap lingkungan karena penggunaan masih terkendali dan tidak mengakibatkan kerusakan lingkungan. Keberadaan kain Jumputan juga tidak memiliki pengaruh yang siginifikan terhadap tata nilai sosial budaya masyarakat lokal ataupun wisatawan yang akan membelinya. Penilaian kain Jumputan pada aspek aksesibilitas sangat terjangkau karena mudah ditemukan dan lokasi pusat produksi masih mudah diakses dari pusat kota.

Penilaian potensi kerajinan tangan unggulan keempat yaitu kerajinan ukiran kayu Palembang. Penilaian kerajinan ukir kayu dari aspek keunikan dinilai unik. Ukiran kayu Palembang memiliki nilai keunikan yang terletak pada motif pola ukiran. Pola ukiran Palembang diantaranya motif tumbuh - tumbuhan seperti patro atau pakis. Motif ukiran kayu dapat diaplikasikan pada beberapa benda seperti lemari, tongkat, mimbar dan meja. Penilaian ukiran kayu pada aspek kelangkaan dinilai langka karena kerajinan asli ukiran Palembang hanya dapat ditemukan di Kota Palembang. Pengrajin ukir kayu Palembang yang masih mempertahankan cara tradisional saat ini hanya sedikit, sebagian menggunakan cara modern untuk mempersingkat waktu pembuatan dan mengurangi biaya pembuatan.

\section{Kesiapan Stakeholders}

Kesiapan Stakeholders termasuk kedalam elemen penting untuk terwujudnya program ekowisata kerajinan tangan di Kota Palembang. Aspekaspek yang terdapat pada kesiapan pengelola diantaranya persiapan produk kerajinan tangan, etika pelayanan kepada masyarakat, keamanan dan keselamatan, kenyamanan dan kebersihan lingkungan dan kebijakan pengelola terhadap program ekowisata kerajinan tangan. Hasil identifikasi terhadap stakehoders menunjukan bahwa Stakeholders sangat siap akan produk kerajinan 
tangan yang akan dijadikan objek dalam program wisata, siap untuk memberikan bentuk pelayanan kepada masyarakat dengan cara senyum, salam, siap untuk menjaga keamanan dan keselamatan dengan mengatur sistem keamanan, siap untuk ikut serta adil dalam membersihkan lingkungan agar area sekitar terjaga, siap mengatur kebijakan terkait produk kerajinan untuk mendukung program ekowisata.

\section{Rancangan Program Ekowisata}

Hasil penilaian asesor terhadap potensi kerajinan tangan unggulan di Kota Palembang merupakan objek dalam perancangan program ekowisata. Ekowisata merupakan kegiatan wisata berkelanjutan dengan memanfaatkan potensi sumber daya yang ramah lingkungan. Program ekowisata ini bertujuan untuk merangsang pertumbuhan ekonomi kawasan dengan kapasitas masyarakat untuk mengelola sumber daya yang berpotensi sebagai daya tarik wisata dan meningkatkan pendapatan melalui pengenalan kegiatan kreatif dan produksi di bidang pariwisata. Selain untuk meningkatkan perekonomian, kegiatan berkonsep ekowisata bermanfaat untuk mempertahankan kearifan lokal yang ada di kawasan Kota Palembang.

Keterlibatan wisatawan secara langsung dalam proses pembuatan kerajinan tangan Kota Palembang dapat dikemas dalam paket program ekowisata. Program ini dirancang sebagai program ekowisata harian berdurasi 7 jam dengan fokus sasaran usia remaja hingga dewasa. Program ekowisata bertujuan untuk mengubah persepektif generasi muda terhadap kerajinan tangan yang bukan hanya sekedar produk siap pakai, akan tetapi pengunjung diajak untuk lebih menghargai proses pembuatan dan kreativitasnya pada setiap produk yang dibuat.

Lokasi-lokasi yang menjadi tujuan kegiatan program ekowisata ini adalah tempat kerajinan tangan itu sendiri. Program ekowisata kerajinan tangan ini diawali dengan pemberian arahan pihak penyelenggara kegiatan kepada wisatawan mengenai rangkaian kegiatan. Seluruh wisatawan harus mengikuti Standar Operational Prosedure (SOP) yang ditentukan demi keselamatan dan kenyamanan para peserta dalam mengikuti kegiatan tersebut. Kegiatan yang dapat diikuti para pengunjung atau wisatawan berupa penelusuran kerajinan tangan Kota Palembang seperti kain Jumputan, Songket, Ukiran Kayu Palembang. Para pengunjung atau wisatawan dapat menyaksikan langsung proses pembuatan kerajinan tangan tersebut. Intepreter menjelaskan proses pembuatan serta pengenalan alat dan bahan yang digunakan dalam pembuatan kerajinan tangan. Wisatawan tidak hanya menyaksikan proses pembuatan kerajinan tangan, akan tetapi mereka dapat terjun langsung mempraktikan pembuatan kerajinan tangan pada proses-proses yang dapat dijangkau oleh para pengunjung atau wisatawan.

Program ekowisata kerajinan tangan ini pun diselingi dengan kegiatankegiatan lain yang memperkenalkan kekhasan Kota Palembang seperti wisata kuliner, wisata belanja, wisata alam dan wisata budaya lainnya. Ekowisata sebagai pariwisata berkelanjutan bertanggung jawab atas segala yang dilakukan di tempat-tempat alami dan berperan dalam melestarikan alam serta meningkatkan kesejahteraan masyarakat setempat. Ekowisata berorientasi pada lingkungan 
berkelanjutan, memiliki nilai pendidikan yang menyertakan masyarakat, dan mendapatkan kepuasan (UNESCO, 2009).

\section{SIMPULAN}

Kota Palembang memiliki empat sumber daya kerajinan tangan yang diklasifikasikan berdasarkan bahan baku yang digunakan. Kerajinan bahan keras dan bahan lunak dibedakan berdasarkan bahan alami dan buatan. Kerajinan yang termasuk ke dalam kerajinan bahan keras alami yaitu kerajinan Ukir Kayu Palembang yang menggunakan bahan utama kayu Tembesu. Kerajinan yang termasuk ke dalam kerajinan bahan lunak yaitu kerajinan Laker, kain Songket dan kain Jumputan. Kerajinan Laker menggunakan bahan getah Ambalau yang telah melalui proses pengolahan oleh pengrajin, kain Songket dan kain Jumputan menggunakan hasil pengolahan serat alam. Hasil penilaian asesor terhadap kerajinan tangan Kota Palembang menunjukan bahwa keempat kerajinan tersebut layak dijadikan objek dalam perancangan program ekowisata karena kerajinan tangan tersebut memiliki tingkat daya tarik yang tinggi dilihat dari keunikan, kelangkaan, keindahan, aksesibilitas dan fungsi sosial. Para Stakeholders pun siap mendukung program ekowisata tersebut dilihat dari aspek produk kerajinan tangan, etika pelayanan kepada masyarakat, keamanan dan keselamatan, kenyamanan dan kebersihan lingkungan dan kebijakan pengelola terhadap program ekowisata kerajinan tangan. Program ekowisata dirancang dengan konsep eksplorasi kerajinan tangan mulai dari memperkenalkan produk, bahan baku, proses pembuatan, interaksi antara wisatawan dengan pengrajin, keterlibatan wisatawan dalam pembuatan produk.

\section{DAFTAR PUSTAKA}

Avenzora R. 2008. Ekoturisme Teori dan Praktek. Banda Aceh: BPR NAD-NIAS. Hasan A. 2015. Tourism Marketing. Yogyakarta: Center for Academic Publishing Service.

Mubarat H. 2016. Kajian Bentuk dan Fungsi Seni Kerajinan Lakuer Tepak Sirih Palembang. Seni Desain Dan Budaya I (6): 1-8.

Sefmiwati. 2016. Pengembangan Pembelajaran Seni Kriya Menggunakan Teknik Pemodelan Berbasis Pendekatan Saintifik. Jurnal Penulisan Guru Indonesia I (1): 37-42.

Soegeng Ysh. AY. 2006. Dasar-Dasar Penulisan Bidang Sosial, Psikologi, dan Pendidikan. Semarang: IKIP PGRI Semarang Press.

Subagyo JP. 2006. Metode Penulisan Dalam Teori Dan Praktek. Jakarta: Rineka Cipta.

Sugiyono. 2010. Metode Penulisan pendidikan: pendekatan kuantitatif, kualitatif dan $R \& D$. Bandung: Alfabeta.

Sugiyono. 2012. Metode Penulisan Kualitatif dan R\&D. Bandung: Alfabeta. 
UNESCO. 2009. Ekowisata: Panduan Dasar Pelaksanaan. Jakarta: UNESCO 